\author{
EDWARD SKIBIŃSKI \\ Instytut Historii Uniwersytetu \\ im. Adama Mickiewicza
}

\title{
O PISANIU RECENZJI I STUDIACH NAD NARRACJAMI. ODPOWIEDŹ NA UWAGI PRZEMYSŁAWA WISZEWSKIEGO*
}

Ut potero explicabo, Cic. Tusc.

Każdy autor oczekuje z zainteresowaniem na wszelkie reakcje czytelników na napisaną pracę. Tak jest i ze mną. Ucieszyła mnie przeto wiadomość o napisaniu recenzji mojej pracy przez Przemysława Wiszewskiego, autora wielu książek, a zatem doświadczonego w pisarstwie historycznym. Prostym zadaniem recenzenta jest analiza zamysłu autorskiego i ocena, w jakiej mierze był on trafiony oraz czy został zrealizowany w toku pracy. Zamiast tego P. Wiszewski w odniesieniu do mojej książki przedstawia inną koncepcję recenzji. Nie znalazłem w niej krytyki zamysłu, który przedstawiłem w Przemianach władzy. Recenzent podchodzi do książki z zewnątrz, przyglądając się jej z pewną pretensją, dlaczego jest taka, a nie inna. Tego rodzaju koncepcja musi budzić moje wątpliwości.

Nim odniesiemy się do uwag recenzenckich, przyjrzyjmy się kryteriom analizy historycznej, jakie proponuje P. Wiszewski. W jej ramach pierwsze pytanie Recenzenta brzmi - ,czy analizowana praca wnosi nowe ustalenia tak pod względem faktów, jak i metody dochodzenia do nich"? Odpowiadam, że moja praca nie dotyczy ustalania faktów ani historiografii zdarzeniowej. Konsekwentnie nie wymyślam w niej nowych metod dochodzenia do nich. Na to ostatnie jest miejsce w odrębnych rozprawach. Praca taka musiałaby być rozprawą teoretyczną. Drugi cel takiej analizy zaproponowany przez Recenzenta ma prowadzić do zbadania, „czy owe ustalenia

${ }^{*}$ P. Wiszewski, Z badań nad zaginionym światem opowieści o przeszłości Polski. Uwagi na marginesie pracy Edwarda Skibińskiego, Przemiany władzy. Narracyjna koncepcja Anonima tzw. Galla i jej podstawy, Poznań 2009, Instytut Historii UAM, ss. 264, 2 nlb., KH 119, 2012, 1, s. 91-103, streszczenie s. 103-104. 
[--] są logicznie uzasadnione". Cóż ma znaczyć postulat badania logic zn e go uzasadniania nowych ustaleń? Czy interpretacja tekstu jest logiczna? W jakim sensie? Co może oznaczać pytanie, „czy sposób prezentacji [- - ] wniosków [- ] jest logicznie uzasadniony"? Nie napisałem książki z dziedziny logiki. Uzasadnienia opierałem na tekstach źródeł w hipotetycznej (nie ma innej) interpretacji, co oznacza, że inni badacze mogą przedstawić różną od mojej. Czy lepsza będzie ta logicznie uzasadniona? Kolejnym kryterium przy analizie pracy historycznej ma być wedle Wiszewskiego odpowiedź na pytanie, „czy sposób prezentacji w recenzowanej pracy celów, etapów dochodzenia do nich oraz wniosków podawanych przez autora jest czytelny i logicznie uzasadniony" . Gdyby logika była wystarczającym narzędziem do analizy prac historycznych, to niepotrzebna byłaby metodyka badań historycznych. Znajomość logiki dostarczałaby wystarczających narzędzi, a logicy byliby najlepszymi historykami.

Taka wiara w logikę jako metodę badawczą pojawia się czasem, ale od dość dawna jest też krytykowana. Zwracał uwagę na kłopoty z logicznym uzasadnianiem w badaniach historycznych już Jerzy Topolski w swoim Wprowadzeniu do historii. Omówił to na przykładzie stosowania zasady niesprzeczności ${ }^{2}$. Ten sam autor w swojej metodologii historii podał pięć sposobów wyjaśniania historycznego, jednak żadnego z nich nie określił jako wyjaśnianie logiczne ${ }^{3}$. Potoczne użycie słowa „logiczny” odwoływałoby się może do braku spójności tekstu, błędów typu non sequitur itd. Takie błędy można znaleźć zapewne również w mojej książce, ale Recenzent tego nie pokazał. Wskazanie ich nie musiałoby koniecznie podważyć uzyskanych wyników, bo logika nie jest tu metodą badawczą. Bardziej skomplikowana logika jest już domeną teoretyków. Zatem w innej dziedzinie badawczej można by posłużyć się logiką dla zbadania tekstu mojej książki. Czy uzyskane wyniki wniosłyby coś nowego do ustaleń na płaszczyźnie badawczej, w ramach której przeprowadzałem analizy, wolno wątpić. Innym problemem jest analiza samej kroniki Galla. Tu zapewne skonfrontowanie rozumowania Galla z wymogami średniowiecznej dialektyki przyniosłoby jakieś korzyści.

Po takiej prezentacji celów, jakie Recenzent stawia historycznej narracji, jego zgłoszone dalej uwagi wymagają również mojego komentarza. Jednocześnie jestem to winien także innym moim czytelnikom, którzy być może chcieliby zapoznać się z odpowiedzią na postawione mi zarzu-

\footnotetext{
${ }^{1}$ Ibidem, s. 99.

2 J. Topolski, Wprowadzenie do historii, Poznań 2001, s. 58 n.

${ }^{3}$ Idem, Metodologia historii, Warszawa 1984, s. 443.
} 
ty. Jednak ponieważ nie przytaczam recenzji w całości, proszę o porównanie moich uwag przy lekturze z tekstem recenzji.

Już pierwsze uwagi Recenzenta dotyczące Przemian władzy muszą budzić wątpliwości. Komentarz do wprowadzonego przeze mnie, za Gerardem Labudą, pojęcia oratura brzmi: „Z kontekstu wypowiedzi możemy wnioskować, że chodzi tu o zespół narracji ustnych, które były żywe wśród poddanych Piastów i tworzyły «kulturę oralną» (s. 149)" ". Pojęcie oratury omawiam w przytoczonym w pracy artykule mego autorstwa, Odczytywanie źródła historycznego (oratura i litteratura - między mitem a historia) (w: Ars scribendi. O sztuce pisania w średniowiecznej Polsce. Katalog wystawy, red. L. Wetesko, Gniezno 2008). W Przemianach władzy w przypisie 173 na s. 61-62, cytując artykuł P. Wiszewskiego, zwróciłem uwagę na pominięcie $\mathrm{w}$ nim problematyki oratury i odesłałem do przytoczonego wyżej artykułu. Ta sprawa została w recenzji pominięta. Samo pojęcie oratury wprowadził u nas G. Labuda we wstępie do drugiego tomu pism Brygidy Kürbis, Na progach historii (Poznań 2001, s. 8). Należy je jednak rozumieć nie jako „zespół narracji ustnych”, lecz szerzej, jako kulturę oralną tak w aspekcie dokonań, jak i wyróżnianej przez badaczy mechaniki funkcjonowania. Problematyka dotycząca kultury oralnej jest w Polsce szeroko dyskutowana. Dysponujemy również zbiorem podstawowych opracowań zagranicznych dzięki pracom grona badaczy (jednym z nich jest Andrzej Mencwel) Seria Communicare - historia i kultura ze znakiem Uniwersytetu Warszawskiego przynosi ciągle nowe opracowania ${ }^{5}$. Pojęcie oratura czy kultura oralna wraz z jej specyfiką może zastąpić zbyt już dziś ogólne teorie Mircei Eliadego.

P. Wiszewski sam jest autorem pracy, która w dużej mierze traktuje o kronice Galla. Jest rzeczą naturalną, że interesują go pewne tylko problemy związane z tą kroniką. Pisze więc: „Ta historyzacja przekazu sprawia, że niezmiernie istotne byłoby określenie podstawowych informacji o badanym źródle jako zjawisku kulturowo-społecznym, aby określić zjawiska, których mogło być częścią, przez które było kształtowane i samo je kształtowało"6.Jednak, jak łatwo się chyba domyślić, nie dotknąłem tego problemu, bo zająłem się innym aspektem dzieła naszego pierwszego kronikarza. Recenzent miałby może rację,gdybym zdecydował się na napisanie monografii kroniki Galla. Jednak mój zamysł był inny. Tematem pracy, jak sam Recenzent zauważa, była narracja kronikarska, nie zaś hipotezy na

\footnotetext{
${ }^{4}$ P. Wiszewski, op. cit., s. 92.

${ }^{5}$ Poza wskazaną serią przegląd najważniejszych tekstów tego nurtu daje tom zbiorczy - Antropologia słowa. Zagadnienia i wybór tekstów, red. G. Godlewski, Warszawa 2003.

${ }^{6}$ P. Wiszewski, op. cit., s. 92.
} 
temat pochodzenia autora, opis zachowanych rękopisów, analiza języka kronikarza czy badanie epoki, w której powstała ta kronika. Zajmowanie się narracją jest problemem oddzielnym, który jednak nie neguje możliwości zajmowania się innymi tematami - jak naiwnie niekiedy myśleli postmoderniści. Co więcej, i jest to jasne nie tylko dla mnie, narracja Galla nie miałaby sensu, gdyby zanegować np. istnienie Polski Bolesława Krzywoustego. Jednak nie powoduje to, że każdy badacz narracji Galla musi zajmować się historycznymi odniesieniami jego kroniki i vice versa. Badanie narracji ma za zadanie analizę sposobów narratywizacji rzeczywistości, jakie dostępne są w zachowanym materiale źródłowym. Są to badania przydatne, choć uboczne. Podstawowe pozostają zawsze badania historyczne. Badania narratywizacji takie, jak wskazałem wyżej, mają sens tylko na gruncie historii pojmowanej w zgodzie z tzw. klasyczną metodą historyczną, którą rozumiem w duchu koncepcji Ernsta Bernheima.

Jak P. Wiszewski rozumie zakres recenzowanej pracy, świadczy jego opinia: „Określanie wzorców narracyjnych (toposów, wątków przejmowanych z innych źródeł, wzorców fabularnych, itp.) należało do podstawowych elementów warsztatu nie tylko przywoływanej przez Autora Brygidy Kürbis (s. 12), ale także Jana Adamusa, Gerarda Labudy, Karola Maleczyńskiego, Mariana Plezi i wielu innych"7. Co można na to odpowiedzieć? Wzorzec narracyjny nie jest ani wątkiem, ani toposem. Każda dziedzina badawcza ma swoją historię. Tak jest też z badaniami nad narracją. Nie jest to dziedzina filologiczna, choć korzystają z niej również badacze literatury. Historyk wykorzystujący w swojej pracy źródła narracyjne odnosi się też do narracji, podobnie jak do języka tekstu, ikonografii itp. Metody takiej analizy zostały przedstawione w odpowiednich podręcznikach metodyki w rozdziałach o krytyce. Nie były jednak tematem mojej książki. Nie zająłem się również w niej toposami i przejmowanymi wątkami, które interesowały niegdyś filologów.

Przyjrzyjmy się choćby znakomitej pracy J. Adamusa 0 monarchii Gallowej (Warszawa 1952).W trzecim, podsumowującym rozdziale, noszącym tytuł całej książki, mamy następujące podrozdziały: prawo oporu, operacje ustrojowe, testament i synowie, doktryna panów przyrodzonych i ideologia dynastyczna, problem absolutyzmu piastowskiego.J. Adamus analizuje narrację u Galla, stawia sobie jednak inne cele badawcze - rekonstrukcję historyczną. Zdarzające się u nas dyskutowanie w ramach dwóch różnych płaszczyzn badawczych zbyt przypomina sławny wiersz Boya „Każdy mówił o czym innym...”.Jak łatwo też przewidzieć, nie prowadzi do konstruktywnych wniosków.

${ }^{7}$ Ibidem, s. 94. 
Dalszy zarzut Recenzenta dotyczy braku szerszej dyskusji nad publikacjami autorów zajmujących się ponoć tematyką, którą podjąłem w swojej pracy: „Cele badań Autora mieszczą się w ramach tematyki podejmowanej tylko w ostatnich czasach przez Jacka Banaszkiewicza, Czesława Deptułę, Z. Dalewskiego, Romana Michałowskiego, P. Wiszewskiego, nie wspominając o badaczach wcześniej zajmujących się tą problematyką (chociażby J. Adamus, Tadeusz Grudziński)" poglądów, ale jest to mniemanie błędne w tym sensie, że podejście każdego z wymienionych przez Recenzenta autorów do tekstu kroniki Galla jest inne. Zatem polemika nie toczyłaby się na tej samej płaszczyźnie, co sprawiłoby zapewne, że byłaby długa i monotonna.

Zarówno J. Adamus, jak i T. Grudziński prowadzą swoje badania w ramach krytyki historycznej, którą ja się w swojej książce nie zajmowałem. Ojcem założycielem badań przeze mnie prowadzonych jest J. Banaszkiewicz. Jego prace stworzyły podstawę dla dalszych działań, również moich. Inaczej sprawa się ma z pracą C. Deptuły, Galla Anonima mit genezy Polski (Lublin 2000). Z koncepcją w niej przedstawioną się nie zgadzam, choć inne analizy tego uczonego cenię i wykorzystałem je również w swojej książce.Z oboma tymi autorami polemizowałem we wcześniejszych artykułach, których P. Wiszewski, jak wnioskuję z jego pracy Domus Bolezlai. W poszukiwaniu tradycji dynastycznej Piastów (do około 1138 r.) (Wrocław 2008), nie zna. Nie wymienił ich przynajmniej w obszernej bibliografii przytoczonej na końcu tej publikacji. Koncepcja Zbigniewa Dalewskiego dotyczy innego aspektu kroniki Galla niż poruszany przeze mnie. Gdybym podjął z nim polemikę, musiałoby to wywołać zdziwienie. R. Michałowski w przytoczonych przez Recenzenta pracach zajmuje się ideologią monarchiczną Piastów, która również nie stanowiła tematu mojej książki.

Tak stanowcze uwagi P. Wiszewskiego mają swoje źródło, jak sądzę, w wyznawanej przez Recenzenta koncepcji analizy kroniki. Spróbujmy dowiedzieć się, co to za koncepcja. Autor przedstawił ją w swojej rozprawie: „Spośród trzech wyszczególnionych przez Gerarda Labudę możliwości odczytania Kroniki: jako źródła do opisywanych dziejów, jako źródła do dziejów w momencie jej spisywania i jako mitu, my wybieramy tę drugą [wyróżn. - E. S.] [-- ]. Siłą rzeczy przeprowadzone tu analizy nie pretendują do kontestowania ustaleń badaczy obracających się w pierwszej - tu dobrym przykładem mogą być nieco zapomniane studia Tadeusza Grudzińskiego, Ze studiów nad kronika Galla. Rozbiór krytyczny pierwszej księgi [- - ] - i trzeciej warstwie rozumienia tekstu Anonima (na przykład Jacek Banaszkiewicz, Czesław Deptuła, Edward Skibiński), ponieważ

${ }^{8}$ Ibidem, s. 94-95. 
mając mniejszy rozmach rozmijają się z nimi" ${ }^{\prime}$. Zatem sam P. Wiszewski wybrał drugą możliwość badań nad kroniką. Na czym ona ma polegać? Zajrzyjmy do cytowanego tekstu G. Labudy, którym jest recenzja książki C. Deptuły: „Do «Podania o Popielu i Piaście» u Anonima Galla i amplifikujących go opowieściach mistrza Wincentego zwanego Kadłubkiem, później zaś Kroniki Wielkopolskiej i Jana Długosza, można przystąpić w trojaki sposób. I tak: a) traktując przynajmniej podanie zapisane przez Galla za część rzeczywistości historycznej i stosując do niej ustalone prawidła krytyki historycznej, poddawać je weryfikacji i w rezultacie poczytywać, tak lub nie, za jeden ze składników najstarszego ogniwa dziejów polskich (tak postępowała tzw. pozytywistyczna szkoła historyków), b) nie ufając faktom i zdarzeniom, lub nie mając możności zweryfikowania wiarygodności tych opowieści, starać się odkryć ich genezę oralną lub literacką, i tym samym odczytywać ich przekaz, jako część rzeczywistości historycznej momentu ich powstania, oraz wreszcie, c) nadając podaniu cechy mitu, czyli rzeczywistości wyobrażonej celem osiągnięcia z góry założonych zadań ideologicznych, starać się odkryć ich sens w świadomości twórców tych opowiadań"10.

Ważna różnica między koncepcjami G. Labudy i P. Wiszewskiego polega na ich zakresie. Podczas gdy G. Labudzie chodziło tylko o opowieść o Piaście i Popielu, P. Wiszewski potraktował koncepcję poprzednika jako odnoszącą się do całej kroniki. Labuda uznał zatem, że można opowieść o Piaście i Popielu potraktować w ramach trzeciego wskazanego przez siebie podejścia. P. Wiszewski wybrał dla siebie drugą z trzech możliwych metod i do niej zaliczył stosowaną w swojej książce metodę analizy tekstu kroniki Galla. Wydaje się to jednak w perspektywie tekstu Labudy nieporozumieniem. Trzecia metoda dotyczy bowiem mitu w bardzo szerokim rozumieniu tego pojęcia, włączającym nawet ideologię. Powoduje to, że Labuda zalicza do tej samej grupy zarówno prace J. Banaszkiewicza, jak C. Deptuły czy R. Michałowskiego. Uważam to za błąd. Jednak dla historyka zajmującego się rekonstruowaniem przeszłości może nieistotny. Tak rozumiany mit nie rejestruje bowiem zdarzenia historycznego w sposób rozpoznawalny dla analizy. To pozwala łączyć różne formy dyskursów w ramach tej grupy.Jednak dla badacza ideologii politycznej czy mitologii nie jest to już tak oczywiste.

Druga grupa łączy oralność (oraturę - wedle późniejszego określenia G. Labudy) z literaturą. Ponownie mamy tutaj do czynienia z dwoma ro-

${ }^{9}$ Idem, Domus Bolezlai, s. 131, przyp. 507.

${ }^{10}$ G. Labuda, rec.: Czesław Deptuła, Galla Anonima mit genezy Polski. Studium z historiozofii i hermeneutyki symboli dziejopisarstwa średniowiecznego, Lublin 1990, St. Źr. 34, 1993, s. 114-116, tu s. 114. 
dzajami tekstów. Literackość przy tym jest tu, jak sądzę, rozumiana jako wprowadzenie elementu z perspektywy współczesnego historyka fikcyjnego, np. mów wygłaszanych przez bohaterów. W tym sensie trzecia grupa obejmuje szerszy zakres czasowy funkcjonowania „narracji” - jako mit i ideologia, druga zaś węższy, ograniczony do momentu spisania. Zasadniczo jednak, jak widać z powyższej argumentacji, P. Wiszewski uznaje przynajmniej teoretycznie rozdzielność podejść do narracji kronikarskiej. Nie widać jednak tego w omawianej recenzji. Zgodnie ze schematem Labudy moja książka musiałaby wpisywać się w drugą grupę wydzielonych przez tego uczonego metod. Zatem przyjmując takie stanowisko, nie musiałbym kontestować prac powstałych w ramach metod pierwszej i trzeciej. Nieporozumienie polega na tym, że ani Labuda nie zamierzał dawać w swojej recenzji uniwersalnej koncepcji, ani moja praca w przytoczonej teorii się nie mieści.

Recenzent odnosi się także do tytułowego problemu pracy, tj. kryzysu władzy. Pisze następująco: „Autor wskazuje, że dyskursy polityczne koncentrują się wokół kryzysów. Opowieść o nich podnosi «wartość semiotyczną» wypowiedzi, której celem ostatecznym jest legitymizacja władzy (s.17-18). Czy jednak zawsze i wszędzie, od antyku po wiek XIX, kryzys był w centrum każdego dyskursu władzy?"11. W powoływanym ustępie napisałem jednak coś innego: „Łatwo zauważyć, że dyskursy polityczne budują się często wokół momentów kryzysowych jako centralnych punktów odniesienia"12. Dlaczego Recenzent zamienił „często” na „zawsze" - nie wiem. Interesująca jest ustanowiona przez Wiszewskiego na wiek XIX granica kryzysów. Jak się wydaje, ustanowienie w tym wypadku jakiejkolwiek granicy musi polegać na nieporozumieniu. Jednak sam problem kryzysów i narracji jest ważny. Jasne, że kronika jest jedną z form metakomentarza do dziejącej się rzeczywistości, komentarza szczególnie ważnego w sytuacji kryzysowej. Tak działała np. tragedia grecka, rozmaite rytuały itd. Budowanie modeli ułatwiało nie tylko ich rozwiązywanie, lecz również wszelki dyskurs społeczny. Dopiero na ich bazie tworzono ideologie ${ }^{13}$.

Kolejna uwaga Autora recenzji dotyczy zagadnienia, czy kronika Galla jest panegirykiem. P. Wiszewski przytacza moją opinię na ten temat „Nie jest to jednak panegiryk, którego władca panujący w społeczności ciągle jeszcze mało posługującej się pismem nie potrzebował, lecz raczej

${ }^{11}$ P. Wiszewski, Z badań nad zaginionym światem, s. 93.

${ }^{12}$ E. Skibiński, Przemiany władzy. Narracyjna koncepcja Anonima tzw. Galla i jej podstawy, Poznań 2009, s. 17.

${ }^{13}$ Por. na ten temat np.V. Turner, Od rytuału do teatru, Warszawa 2005 (oryg. ang. 1986), s. $172 \mathrm{n}$. 
obrona w związku ze sprawą spowodowanego przez niego okaleczenia starszego brata Zbigniewa i odbytą pokutą". Uwaga, która zainteresowała P. Wiszewskiego, dotyczy problemu, którym się w pracy nie zajmowałem. Poruszyłem go tylko dwa razy w całym tekście. Wynikało to nie tylko z odmiennego ukierunkowania mojej książki, lecz również z faktu, że częściowo dotknąłem tej kwestii na krakowskiej sesji o Gallu i jego kronice (w 2007 r.), a w chwili wydania mojej książki materiały z konferencji jeszcze nie ukazały się drukiem. Na sesji tej P. Wiszewski był obecny. Poważniejszym argumentem jest odmienny temat mojej pracy. Nie zajmowałem się w niej retoryką kroniki Galla. Zagadnienie jest jednak nieskomplikowane, więc pozwolę sobie je pokrótce przedstawić. Panegiryk jest formą laudacji, czyli pochwały. Wedle teorii retoryki są trzy rodzaje wymowy: wymowa sądowa - genus iudiciale, wymowa doradcza - genus deliberativum, wymowa pokazowa - genus demonstrativum. Każdy rodzaj wymowy dzieli się na dwie odmiany przeciwstawne. Mianowicie - wymowa sądowa na oskarżenie i obronę; wymowa doradcza - na doradzanie i odradzanie, ostatnia zaś wymowa pokazowa na pochwałę i naganę. Przedmiotem pochwały są cnoty osoby chwalonej. Tradycyjnie winny to być cnoty kardynalne. Jeżeli zatem Gall napisał pochwałę - a nawet panegiryk Bolesława Krzywoustego, to powinien przedstawić te właśnie cnoty. Na s. 138 mojej książki przeprowadziłem analizę przemowy Władysława Hermana dotyczącej jego obu synów, tj. Zbigniewa i Krzywoustego. Tu po raz drugi i ostatni użyłem w tej pracy słowa panegiryk. Nie ma w tej przemowie pochwały Krzywoustego, choć wskazane są zapewne jego ewentualne zasługi, które dadzą mu w przyszłości władzę. To, co musi dziwić w kronice Galla, to właśnie skąpe użycie terminologii dotyczącej cnót kardynalnych w odniesieniu do naszych władców. Podobnie jak określenie król - rex, tak również virtutes cardinales w kronice pojawiają się rzadko. W pracy przedstawiłem dość szczegółową analizę użycia przez Galla cnót kardynalnych w prezentacji zasług omawianych w tekście władców. Recenzent jednak tego nie zauważył. W świetle tej właśnie analizy jest nie do utrzymania teza P. Wiszewskiego, który pisze - „Tym bardziej że sam kronikarz stylizuje kronikę, zwłaszcza dwie ostatnie księgi, jednoznacznie na panegiryk"14.

Przytoczone przez Recenzenta określenia użyte przez Galla w prologu „gloriosissimi ducis ac victoriosissimi” odnoszą się do darów fortuny, a nie do cech wewnętrznych władcy, którymi są cnoty - virtutes. Jakie cnoty Krzywoustego chwali Gall? Odsyłam do mojej książki. Inny problem stanowi zagadnienie - jaki jest potencjalny adresat laudacji i czym się różni od

${ }^{14}$ P. Wiszewski, Z badań nad zaginionym światem, s. 92. 
adresata apologii? Odpowiedź wydaje się dość prosta. Formą pochwały są np. pomniki, a adresatem takiej formy są z natury wszyscy. Zachwyt nie wymaga na ogół wiedzy. Inaczej ma się sprawa $\mathrm{z}$ apologią - jest to forma obrony i z natury jest skierowana do węższej grupy odbiorców, świadomych reguł gry, odpowiednich zasad. Argumentacja sądowa wymaga znajomości prawa, teologiczna - teologii. Jakiego odbiorcy potrzebuje tekst fachowy z zakresu historii, choćby książka P. Wiszewskiego czy moja? I podobnie jak rozprawa prawnika czy teologa - ilu będzie miała czytelników? Myślę, że refleksja nad tymi problemami lepiej pozwala zrozumieć sytuację komunikacyjną, w którą jest wpisana nasza kronika.

Dzieło Galla zajmowało na przestrzeni ostatnich ponad dwustu lat bardzo wielu uczonych. Nie dysponujemy obecnie żadnym wykładem stanu badań nad tą kroniką. Nie dał jej również P. Wiszewski w swojej książce. Brak w niej np. ważnej pracy Teodora Tyca ${ }^{15}$, artykułów Andrzeja Biernackiego, ważnych metodycznie prac Kazimierza Tymienieckiego, brak książki Augusta F. Grabskiego Polska w opiniach obcych X-XIII w. (Warszawa 1964). Brak również dyskusji Zofii Budkowej z K. Maleczyńskim na temat wydania kroniki, dyskusji przynoszącej nowe ustalenia w sprawie filiacji tekstu. Brak również moich prac (z dotyczących kroniki Galla cytuje tylko jedną). Omówienie wszystkich tych badań wymaga różnorodnego podejścia, pozwalającego ująć choć zarysy koncepcji przedstawionej przez ich autorów. $\mathrm{Z}$ drugiej zaś strony polemika w przypisach przy takich różnicach nie spełniałaby wymogów porządnej dyskusji.

Jak Recenzent rozumie moją książkę, świadczy na przykład takie jego spostrzeżenie: „Rozdział drugi E. Skibiński poświęca problemowi utraty i odzyskania władzy przez Piastów". Omawiany rozdział drugi należy jednak do części zatytułowanej: „Zdarzenia - dominanty w świetle narracji". Chodzi więc o opowiadanie kronikarza, a nie o realne zdarzenia. Wiemy z dziejów najnowszych, że narratywizacja historii również wpływa na los jej sprawców. Tak bywa w procesach sądowych i w polityce. Jednak odróżnianie mapy od terytorium, które przedstawia, jest od czasów Alfreda Korzybskiego czynnością banalną, podobnie opowiadania od rzeczywistych zdarzeń ${ }^{16}$.

Jak sygnalizowałem w omawianej pracy, koncepcja moja opiera się na zasadach źródłoznawstwa historycznego w ujęciu B. Kürbis. Sam termin bywa u nas jednak używany szerzej i stąd zapewne nieporozumienia. Wprowadził go Karol Szajnocha oraz tłumacze książki H. Zeissberga

15 T. Tyc, Anonim - biograf trzeciego Bolesława, „Przegląd Warszawski” 4, 1924, 31, s. 55-77.

${ }^{16}$ G. Bateson, Umysł i przyroda, Warszawa 1996 (oryg. ang. 1979), s. 47 n. 
jako odpowiednik niemieckiego Quellenkunde ${ }^{17}$. Obecnie oddajemy ten niemiecki wyraz przez określenie heureza historyczna. Zatem termin „badania źródłoznawcze” może dotyczyć heurystyki lub też krytyki historycznej (krytyka pochodzenia). Źródło historyczne musi być obecne na każdym etapie badań historycznych. W każdym przypadku badacz musi też uwzględniać kontekst historyczny, również ten imaginacyjny, właściwy dla danej epoki. Opowieści uznawane za prawdziwe rządzą się innymi prawami niż te, które funkcjonują jako fikcja literacka. Są jednak również opowieściami, tj. mają swoją fabułę, narratora itd. „E. Skibiński podkreśla konieczność uchwycenia związków treści dzieła z minioną rzeczywistością. W skazuje, że należy «traktować tekst jako element świata, do którego się odnosi, a nie jako niezależny rodzaj bytu. [...] jest to zgodne z traktowaniem źródła pisanego jako pozostałości, czyli właśnie elementu świata minionego. Świat ten jako punkt odniesienia był jednak jakoś narratywizowany, w ramach dyskursu, którego badany tekst był elementem» (s. 18). Ta historyzacja przekazu sprawia, że niezmiernie istotne byłoby określenie podstawowych informacji o badanym źródle jako zjawisku kulturowo-społecznym, aby określić zjawiska, których mogło być częścią, przez które było kształtowane i samo je kształtowało. Jednak Autor, określając nadawcę zawartego w kronice komunikatu, jego cel i odbiorcę, posługuje się ogólnikami. Pomija niemal w całości dotychczasową refleksję źródłoznawczą związaną z genezą źródła, przedstawia zaś hipotezy jako pewniki"18.

Zanim zajmę się odpowiedzią na te zarzuty, muszę wnieść poprawkę do wywodu Recenzenta. Genezą źródła zajmuje się krytyka historyczna i w ramach jej metodyki przebiegała większość dotychczasowych dyskusji nad Gallem. Zgodnie z zapowiedzią nie zajmowałem się krytyką historyczną tekstu kroniki. Cel, jaki sobie postawiłem, był inny: „Zadaniem w niej postawionym jest więc zbadanie narracyjnej koncepcji przemian władzy w kronice Anonima tzw. Galla. W tym sensie traktuję opowiadanie Anonima jako fakt źródłowy, który cechuje się określoną budową jako komunikat przeznaczony dla swoich współczesnych"19. Nie zajmowałem się więc całą kroniką we wszystkich jej aspektach. Recenzent zdaje się to dostrzegać, stwierdza bowiem: „Pomija niemal w całości dotychczasową refleksję źródłoznawczą związaną z genezą źródła" ${ }^{20}$. Zarzuty recenzenta wytykają mi, że nie napisałem tego, czego nie chciałem napisać. Narracje polityczne

${ }^{17}$ H. Zeissberg, Dziejopisarstwo polskie wieków średnich, t. 1-2, Warszawa 1877 (oryg. niem. 1873).

${ }^{18}$ P. Wiszewski, Z badań nad zaginionym światem, s. 92.

${ }^{19}$ E. Skibiński, op. cit., s. 15.

${ }^{20} \mathrm{P}$. Wiszewski, Z badań nad zaginionym światem, s. 92. 
mające na celu właściwą ze względu na realizowane interesy narratywizację rzeczywistości nie są dowolne. Muszą przecież również dostarczyć narzędzi na przyszłość.

Dziewiętnastowieczna powieść i heglowska filozofia historii nauczyły nas doszukiwać się wielkich narracji również w dziełach przeszłości. Kronika jednak nie jest powieścią i na ogół odległa jest od wielkich koncepcji historiozoficznych. Pisząc, że Gall stworzył swoją kronikę, opierając się na rozmaitych próbach narratywizacji przeszłości, odwoływałem się też do koncepcji Haydena White'a i innych badaczy ${ }^{21}$. To, że różne grupy polityczne mają rozmaite narracje na temat zdarzeń przeszłych, wydawało mi się sprawą banalną, niewymagającą szerszego uzasadnienia. Kronika jest, jak wiadomo, również pewnym faktem historycznym. To pogląd źródłoznawców sprzed trzydziestu lat. Już jednak wtedy zdawano sobie sprawę, że można pójść dalej. Faktem historycznym jest również narracja kronikarska. Takie porównawcze badanie narracji średniowiecznych prowadzi w tej chwili wielu mediewistów.

Od czasu prac Michaiła Bachtina (Mihail Bahtin) na temat dialogu w kulturze wiemy, że koncepcja tekstu jako monologu, na którego kształt ma wpływ tylko zamysł autora, jest błędna ${ }^{22}$. Teksty prowadzą dialog odpowiadają i stawiają pytania, ale też wchłaniają cudze ujęcia. Potraktowałem kronikę jako zbiór opowiadań historycznych: „Kronika reprezentuje bowiem próbę zapisu opowiadań o rzeczywistości dawnej i bliższej czasowo" (s. 11) ${ }^{23}$. Uznałem, że to oczywiste dla każdego czytelnika tekstu kroniki. Nie ma w tekście wyraźnych wskazówek, że jest inaczej. Dotyczy to przede wszystkim księgi pierwszej. W dwóch następnych sytuację zmienia jednolity punkt odniesienia, czyli panujący władca Bolesław Krzywousty. Jak łatwo można się przekonać, tym dwóm księgom poświęciłem znacznie mniej miejsca. Wynikało to z przyjętej szerszej perspektywy. Kryzys władzy spowodowany konfliktem Bolesława ze Zbigniewem zreinterpretowałem na tle narracji o wcześniejszych dziejach Piastów. W tych opowieściach w przeciwieństwie do Recenzenta dla mnie kluczową postacią jest Kazimierz Odnowiciel. Zderzenie się z problemem rozpadu państwa, jaki obserwowały elity polityczne jego czasów, stało się doświadczeniem podstawowym dla ich następców. Następne kryzysy były interpretowane przez pryzmat tego pierwszego. Ostateczne rozwiązanie, które wybrał Bolesław Krzywousty - pokuta władcy - było w naszej

${ }^{21}$ E. Skibiński, op. cit., s. 16; H. White, Poetyka pisarstwa historycznego, red. E. Domańska, M. Wilczyński, Kraków 2010; Narratologia, red. M. Głowiński, Gdańsk 2004.

${ }^{22}$ Krytyczna analiza dyskursu. Interdyscyplinarne podejście do komunikacji społecznej, red. A. Duszak, N. Fairclough, Kraków 2008, s. 12.

${ }^{23}$ E. Skibiński, op. cit., s. 11. 
historii ewenementem. Zostało też przez naszą historiografię wyparte, począwszy od kroniki mistrza Wincentego. Pisząc o elitach politycznych, nie mogłem niestety wskazać wśród ich przedstawicieli nosicieli tych czy innych poglądów. Jest to zadanie na inną pracę, wymagające innej metodyki badań.

Analizując opowiadanie kronikarza o Mieszku II i Kazimierzu Odnowicielu, nie wprowadziłem Kroniki z Brauweiler ${ }^{24}$ niezależnie od tekstu Galla. Przeciwnie, jak wskazałem, kronika klasztorna daje komentarz do zwięzłej charakterystyki Mieszka II podanej przez naszego Anonima. Recenzent nie dostrzegł tego w swojej analizie mojego tekstu. Podobnie nie oskarżałem Mieszka II o bigamię, lecz o wielożeństwo. Co nie jest hipotezą tak dziwaczną dla tej epoki. Jak wynika z Kroniki z Brauweiler, Rycheza podjęła ryzyko ucieczki po rozwodzie (divortium) spowodowanym nienawiścią i działaniami jakiejś nałożnicy Mieszka II. Uciekła w przebraniu, bez zgody „byłego” męża. Divortium jestem skłonny tutaj traktować jako uzasadnienie ucieczki podane na użytek odbiorcy, który realiów polskich nie znał. Nie chodzi więc o jedną więcej kochankę, ale o pojawienie się „stałej partnerki”. Rzecz wymaga zapewne dalszej analizy, moją hipotezę jednak wspiera pojawienie się drugiej żony Mieszka II w narracji mistrza Wincentego.

Pisze recenzent: „Kronikarska narracja dotycząca dziejów i upadku Zbigniewa służy Autorowi do wykazania, że w pierwotnej - ustnej i nieutrwalonej nigdzie w tym kształcie - wersji opowieści ukazywano Sieciecha jako stronnika Krzywoustego, a przeciwnika Zbigniewa"25. Taka metoda argumentacji ma służyć sprowadzeniu ad absurdum mojego rozumowania. Polega jednak na nieporozumieniu. Nie odwołuję się do nieistniejącego źródła, a swoje analizy opieram na kronice Anonima. Zakładam bowiem, że w tego rodzaju wypowiedzi, jaką jest kronika, możliwości ukrywania prawdy były ograniczone przez krąg odbiorców. Nie można było kłamać w sprawach wszystkim znanych. Zatem elementy tej narracji pozytywnej dla Zbigniewa znalazły się w kronice Galla. Nasz kronikarz był jednak skutecznym propagandzistą - widać to nawet w tendencyjnym tłumaczeniu Galla, którym się wszyscy posługujemy (jak to pokazałem w swojej pracy).

W swojej pracy analizę narracji kryzysów władzy w świetle kroniki Anonima uznałem za cel główny. Nie jest to więc praca z zakresu klasycznych tematów historii. Badając narrację - nie zajmowałem się ani autorem, ani pragmatyką jego dzieła. Pracę swoją napisałem w ramach koncep-

${ }^{24}$ Brunwilarensis monasterii fundatorum actus, red. G. Waitz, MGH SS, t. 14, Hannoverae 1883, s. 123-146; E. Skibiński, op. cit., s. 86 i n.

${ }^{25} \mathrm{P}$. Wiszewski, Z badań nad zaginionym światem, s. 96-97. 
cji źródłoznawstwa B. Kürbis, co zresztą zaznaczyłem. Zarzuty Recenzenta rozmijają się więc z celem recenzowanej książki. Nie śledził zapewne moich wcześniejszych prac, co utrudniło mu interpretację tej ostatniej. Kronika jest oczywiście opowieścią o zdarzeniach rzeczywistych tak dla tego, kto ją spisuje, jak dla jego odbiorców. Opowiadanie o rzeczywistości nie jest jednak samą tą rzeczywistością, nawet rozumianą narracyjnie. W tekście pomija się sprawy powszechnie znane, ale też niewygodne. Wiele przykładów tego rodzaju postępowania znajdziemy z łatwością na naszej scenie politycznej. Opowiadania takie nie są układane dowolnie. Ich struktura nie zależy wyłącznie od woli autora. Opowieści o rzeczywistości, żeby były odbierane jako takie, muszą odnosić się do zdarzeń uznawanych za autentyczne. Mówimy zatem o jakimś postrzeganiu rzeczywistości na poziomie zdarzeniowym. Na czym polega kompozycja takich opowieści? Posłużyłem się prostym pomysłem Borysa Tomaszewskiego dotyczącym dominant narracyjnych. Badanie narracji przypomina tu zatem badanie tekstologiczne rozpatrujące kolejność wyrazów w ramach wypowiedzi. Ma ona oczywiście rozmaite znaczenia dla psychologa, badacza retoryki, językoznawcy itd. Podobnie jest z badaniem narracji.

Ideologia polityczna jest czymś bardziej wyspecjalizowanym, choć też musi się opierać na postrzeganiu rzeczywistości. Cel badania wiąże się z perspektywą badacza. Wszystko inne, a więc również obiekt poszukiwań, jest konstruowane zgodnie z nim. Sprawia to, że badanie takich opowiadań może być celem samym w sobie. W oparciu o te badania analizowano inne jeszcze tematy, np. ideologię polityczną. Czy powinienem się włączyć już w mojej książce w te rozważania? Uważam, że nie. Polemizując z jakimś stanowiskiem naukowym, jestem zobowiązany w pełni ujawnić własną argumentację. Dyskusje cząstkowe, pomijające całościowe stanowisko autora, stwarzają tylko pozór polemiki naukowej. W polemikach historycznych, odwołujących się do wspólnego warsztatu metodycznego wypracowanego dawniej, nie ma potrzeby trzymać się takiego stanowiska. Metoda jest znana, wskazanie więc na własne wątpliwości opiera się na technice badawczej stosowanej przez innych historyków. Tak się dzieje w badaniach nad rekonstrukcją historyczną (etap syntezy historycznej, czasem nazywanej interpretacją). Sam nie unikam tego rodzaju dyskusji.

Badania nad naszymi kronikami są dobrym probierzem rozejścia się rozmaitych dyscyplin mediewistyki. Rozmaitość podejść badawczych sprawia, że zdarzają się spory chybione, jak w tym przypadku. W swojej pracy zaproponowałem pewne rozwiązania, które uznaję za hipotetyczne. Nie jest to wyraz skromności, lecz uświadomienia sobie sytuacji, w jakiej znajdują się mediewiści zajmujący się naszymi najstarszymi 
dziejami. Wypada teraz przeanalizować, które hipotezy są mocniejsze, które słabsze.

Recenzja pełna tylu nieporozumień zniechęca do dyskusji. Być może jest na nią jeszcze zbyt wcześnie. Żeby zająć się dyskusją nad kroniką Galla, która toczy się już od ponad dwustu lat, należałoby uwzględnić każdorazowo właściwy kontekst epistemologiczny kolejnych wypowiedzi. Wziąć pod uwagę to, w ramach jakich płaszczyzn badawczych były prowadzone dawne spory. Jest to cel, który może zostać zrealizowany przy uwzględnieniu prac mediewistów zajmujących się badaniami narracji w Europie Środkowej i Wschodniej. Dociekania takie musiałyby ująć również koncepcje starsze. U nas będą to np. rozprawy K. Tymienieckiego i wcześniejszych jeszcze badaczy przynajmniej od szkoły Adama Naruszewicza.

Podejmując dyskusję z artykułem recenzyjnym P. Wiszewskiego, warto może jeszcze wskazać na pewne ogólne metodyczne przesłanki pracy nad narracją kronikarską. Pierwszym zagadnieniem powinno być miejsce tego rodzaju badań w historiografii. Każdy dobrze rozumie, że protokół dokumentu wymaga innej analizy niż np. użyte w dokumencie pismo. Jeszcze inaczej badać należy narrację. Opowiadania tworzą samodzielne całości i jako takie powinny być analizowane. Oznacza to, że nie pytamy o wiarygodność, powiedzmy, rozdziału kroniki poświęconego sprawie św. Stanisława, lecz o to, częścią jakiego opowiadania jest fragment tekstu Galla poświęcony tej sprawie. Umieszczenie go w większej całości daje nam podstawy do badań poświęconych ewaluacji poszczególnych zdarzeń występujących w analizowanych tekstach. Wartościowanie ustala rangę zdarzeń w ich ciągu, również hierarchię przyczyn i skutków. Takie poszukiwania muszą jednak najpierw być prowadzone w ramach określonych rodzajów czy typów narracji. Można tak badać np. współczesne formy narratywizowania przeszłości. Opierają się one w jakiś sposób na rzeczywistych zdarzeniach. Jednak ciąg zdarzeń nie tworzy sam z siebie fabuły - potrzebuje interpretacji. Analiza takich narracji przedstawiających ciągi zdarzeniowe jest innym zagadnieniem niż np. badanie powtarzalnych motywów. Przyjmując tę ostatnią koncepcję, zakładamy, że narratywizacje składają się z mniejszych modułów, klocków - nazwijmy je motywami. Badanie tych klocków jest czymś innym niż badanie całych narracji, choć ostatecznie może się zdarzyć, że specjalista od klocków nie lubi specjalisty od większych całości i na odwrót. Jednak ich pole badawcze jest różne. Historyk, który bada przeszłość za pomocą dostępnych źródeł, korzysta również np. z kronik. Badacz dziejów Mieszka Starego może np. zestawić opinię o tym władcy, jaką znajdzie w kronice mistrza Wincentego, z zachowanymi egzemplarzami monet bitych na jego polecenie. Co współtworzy taką całość? Wszystkie elementy opowiadania - 
również te fantastyczne, które traktujemy jako fikcyjne, zwykle utożsamiając je z fikcją literacką. Jednak ta ostatnia kieruje się innymi regułami. Fikcja literacka jest tworzona, sc. wymyślana przez autora. Cechuje się na ogół spójnością. Różni się jednak znacznie np. od materiału, jakim posługiwał się twórca tragedii antycznej. Ajschylos czy Sofokles nie stwarzali swoich fabuł. Widza nie zaskakiwała zagadka postawiona Edypowi przez Sfinksa, bo ją znał. Podobnie było (i jest) z historykiem. Jego koncepcje rozpoznajemy na podstawie całości narracyjnych prezentacji wyników jego badań. Bywa czasem pesymistą, czasem optymistą - dziejów jednak nie wymyśla. Tę funkcję pełni specjalista od ideologii. Ideolog nadaje większą spójność opowiadaniu historycznemu niż historyk. Ma też realną władzę, żeby takie historyczne wizje narzucić. Historykiem jednak nie jest.

Spójrzmy jednak ponownie na tragika i historyka. Obaj wypowiadają się na temat rzeczywistości, mogą też być za to ukarani. Ich indywidualność broniła się dzięki temu, że nie łączyli się na ogół w sposób jawny z ruchami politycznymi. Ludzie postrzegają swoje losy jako tragiczne bądź komiczne. Pozwala to kronikarzowi, który idzie ich śladem, dać im wyraz. Kronikarz, który się do tych spraw ustosunkowuje, musi opierać się na tych społecznych konstrukcjach. Co będzie, gdy je opuści? Jego narracja zostanie odrzucona.

Powróćmy na chwilę do samej metodologii zaproponowanej przez G.Labudę.Przede wszystkim należy jeszcze raz zaznaczyć, że propozycja tego uczonego odnosi się nie do całej kroniki, lecz tylko do opowieści o Piaście i Popielu. Schemat jest też próbą pewnego ogólnego ujęcia problemu w odniesieniu do pracy C.Deptuły. W praktyce dysponujemy czymś pośrednim. Zapis kronikarski nie jest ani mitem, ani ideologią. Nie należy też do kultury oralnej - ustnej, skoro został spisany, i to po łacinie. Inaczej niż P. Wiszewski odrzuciłem w swojej pracy przyjmowane przez Aleksandra Brücknera traktowanie kroniki Galla jako powieści. Mój Recenzent, akceptując ją, nie zapoznał się jednak z polemiką pióra T. Tyca z poglądami berlińskiego filologa, która choć zwięzła, jest jedną z najważniejszych wypowiedzi w tej materii. Uznałem, że kronika pisana, jeśli wierzyć zawartym w tekście deklaracjom, przy współpracy kanclerza Michała, nie przekazuje indywidualnego stanowiska Anonima Galla. Szukając klucza dla interpretacji zawartej w niej narracji, posłużyłem się kulturologicznymi pracami rosyjskimi, traktującymi piśmiennictwo jako przynależące do dyskursu,który nie ogranicza się tylko do tekstów pisanych (ujęcie filologiczne). Odnosząc się do postrzeganej społecznie rzeczywistości, która ma wymiar historyczny, narracja daje się analizować przez wskazanie sterujących nią dominant. Wskazanie kolejnych załamań władzy monarszej jako sterujących narracją 
nie może być zaskoczeniem. Jakie są jednak tego konsekwencje? Nie wiemy dokładnie, jak przebiegały wydarzenia, które doprowadziły do śmierci św. Stanisława. Pokazałem jednak, że postrzegano je jako powtórzenie sytuacji z czasów tzw. reakcji pogańskiej. Podobna obawa, jak sądzę, zaistniała przy interpretacji walki między Zbigniewem i Krzywoustym. Takie badanie nie dotyczy jednak ideologii, która nawet mając wydźwięk historyczny, odnosi się do czegoś innego. Odpowiedź na pytanie, czy koncepcja C. Deptuły, która daje się wpisać w kontekst średniowiecznej interpretatio Christiana, broni się w tym ujęciu, wymaga odrębnej analizy. Problemem istotnym byłoby, czy zakonnik piszący kronikę zreinterpretował legendy o początkach dynastii Piastów w kategoriach schematów starotestamentowych. Nie przekonała mnie książka C. Deptuły. Jego polemika z J. Banaszkiewiczem jest moim zdaniem chybiona. Może jednak dalsza dyskusja przyniesie tu nowe wyniki.

Recenzentowi, jak się zdaje, bardziej odpowiadają moje rozważania o mitologii, choć właściwie nie dyskutuje ich zbyt głęboko. Omówienie sprawozdawcze, które jest właściwie opowiadaniem bez uwzględnienia podstaw stawianych przeze mnie wniosków, bez odniesienia się do analizowanego przeze mnie tekstu, nie daje czytelnikowi podstaw do sądów o mojej argumentacji. Analiza opowieści mitologicznych naszych kronikarzy stała się właściwie pierwszym celem samodzielnych badań nad narracją. Zetknięcie się z dyskutowanym u nas E. Bernheimem i jego teorią augustyńskiego światopoglądu stało się dla mnie impulsem do zastosowania nowszych pomysłów w tego rodzaju badaniach ${ }^{26}$. Bernheim i jego uczniowie pokazali, jak budowano narrację polityczną pod wpływem schematów i kategorii augustyńskich. Warto pójść dalej i zbadać tego rodzaju narracje z punktu widzenia ich budowy i dominant, wokół których były organizowane. Próbę takiej analizy przedstawiłem w swojej pracy.

Ostatnie problem, na który warto zwrócić uwagę, dotyczy wartości zaproponowanej przeze mnie analizy narracji dla rekonstrukcji historycznej. Myślę, że da się ona wykorzystać w ten sposób i zapewne pokuszę się o taką propozycję. Będzie to jednak już inny rodzaj analizy historycznej niż ta, którą przedstawiłem w książce Przemiany władzy.

${ }^{26}$ Por. A. Kuligowska, „Klasyczne” metody interpretacji historycznej na przykładzie bernheimowskich rozważań nad Ruotgeri Vita Brunonis, w: III Polsko-czeskie forum młodych mediewistów, Poznań 2013, s. 127-137. 